\title{
A new record of the Cuban endemic mayfly Poecilophlebia pacoi (Kluge, 1994) (Ephemeroptera, Leptophlebiidae) from Gran Piedra massif, eastern Cuba
}

\author{
Juan Carlos Salazar-Salina $^{1 *}$, Yusdiel Torres-Cambas ${ }^{2}$ \\ 1 Departamento de Biología y Geografía, Universidad de Oriente, Santiago de Cuba, Cuba • juancarlossalazarcu@gmail.com ( http://orcid.org/ \\ 0000-0003-3796-8691 \\ 2 Leibniz Institute of Freshwater Ecology and Inland Fisheries, Berlin, Germany • yusdiel.torres-cambas@igb-berlin.de @ https://orcid.org/0000- \\ 0003-2312-2329 \\ * Corresponding author
}

\begin{abstract}
The endemic mayfly Poecilophlebia pacoi (Kluge, 1994) was described from the Turquino massif, Sierra Maestra mountain range, Cuba. To date, it has only been reported from two river catchments within the country. Distribution of P. pacoi extends up to Gran Piedra massif of Sierra Maestra mountain range. Additionally, previous and new localities are georeferenced and mapped. The new record expands the known distribution range of $P$. pacoi approximately 55 $\mathrm{km}$ to the east.
\end{abstract}

\section{Keywords}

Baconao River, protected areas, streams, leaf packs

Academic editor: Inês Corrêa Gonçalves | Received 1 February 2021 | Accepted 19 May 2021 | Published 4 August 2021

Citation: Salazar-Salina JC, Torres-Cambas Y (2021) A new record of the Cuban endemic mayfly Poecilophlebia pacoi (Kluge, 1994) (Ephemeroptera, Leptophlebiidae) from Gran Piedra massif, eastern Cuba. Check List 17 (4): 1103-1106. https://doi.org/10.15560/17.4.1103

\section{Introduction}

Poecilophlebia pacoi (Kluge, 1994) (Leptophlebiidae), the single representative of the monospecific Poecilophlebia, is a Cuban endemic species of mayfly from the mountains of eastern Cuba (Naranjo et al. 2019). Poecilophlebia pacoi was described from Arroyo Paco (Rio Palma Mocha), Turquino massif, south slope of the Sierra Maestra mountain range (Kluge 1994) (Fig. 1). This is considered a rare species due to the low frequency it has been recorded (Kluge 1994; Naranjo et al. 2019. Later records include additional localities from the headwaters of Cauto River, north face of the Sierra Maestra, $60 \mathrm{~km}$ east from the type locality (Fig. 1) (Deler-Hernández et al. 2007). Here, we report a new record of P. pacoi which extends its known range to the Gran Piedra massif of the eastern Sierra Maestra (Fig. 1).

\section{Methods}

Nymphs were collected with a D-frame net from the bottom leaves of a tributary stream of Baconao River $\left(19.995^{\circ} \mathrm{N}, 075.581^{\circ} \mathrm{W}\right)$ and preserved in $90 \%$ ethanol. Water temperature, $\mathrm{pH}$, conductivity, dissolved oxygen, 


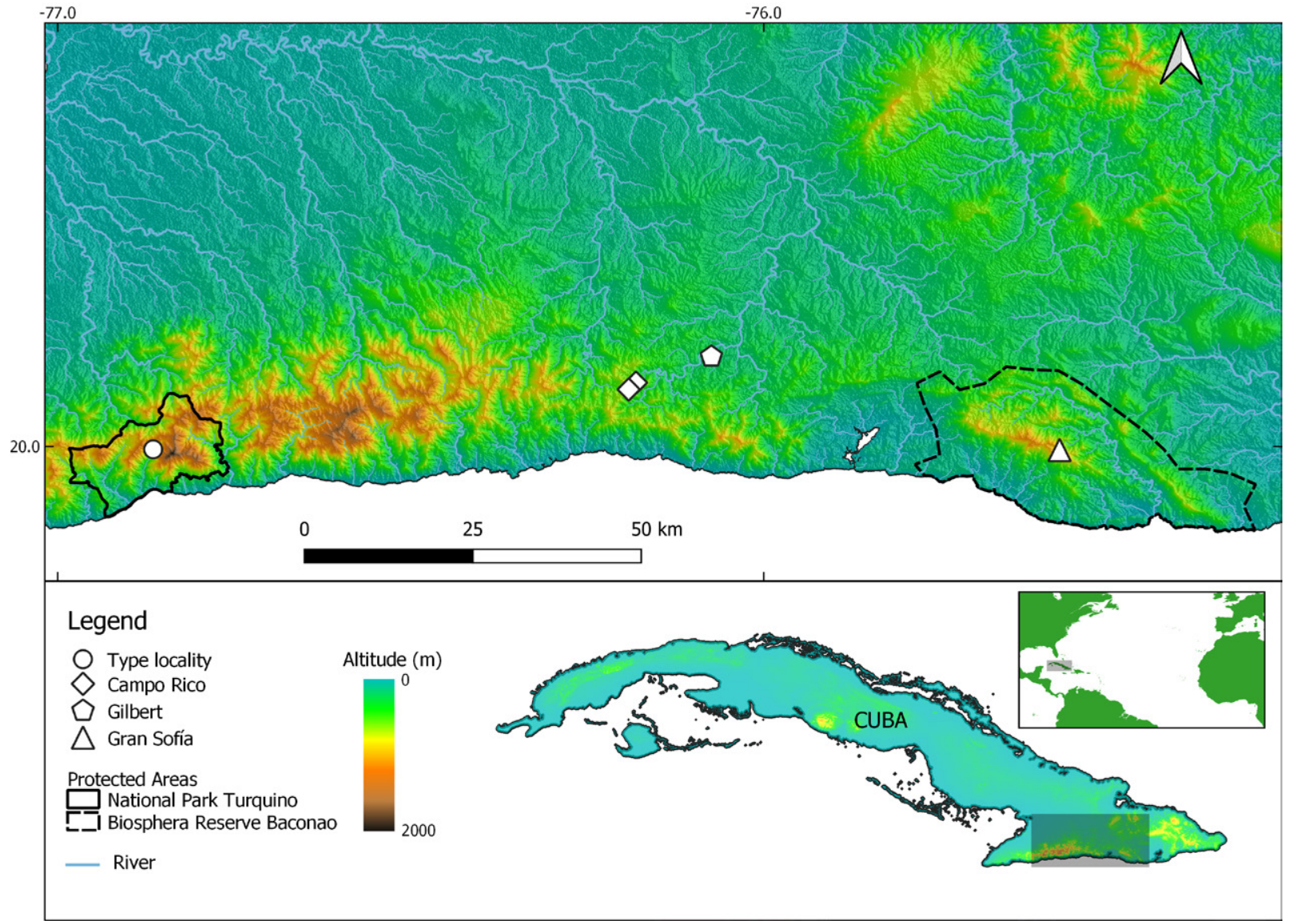

Figure 1. Sampling localities of Poecilophlebia pacoi in Cuba. Arroyo Paco: type locality (Kluge 1994). Campo Rico and Gilbert: localities at headwaters of Cauto river (Deler-Hernández et al. 2007). Gran Sofía: new record from the present research. Protected areas where the species occur are shown.

and total dissolved solids were measured with a DZB-718 Portable Multi-Parameter Water Analysis Meter (Yantai Stark Instrument Co. Ltd., http://starkinstrument.com/). Water current velocity was estimated measuring displacement time of a floating wood object in a 5-m transect. Keys by Gonzáles-Lazo and Naranjo (2007) and Naranjo et al. (2019), as well as the original description of the nymph (Kluge 1994), were used for the taxonomic identification. Voucher material was deposited in Museo de Historia Natural "Charles Ramsden" (CZCTR), Facultad de Ciencias Naturales y Exactas, Universidad de Oriente, Santiago de Cuba, Cuba.

The nymph was photographed with a Canon EOS 700D camera (http://www.canon.com.cn) attached to a stereomicroscope NSZ-808, or a microscope N800-M, both from Novel Optics (http://www.jnoec.com), using a Cold Light L-150A illumination source (Hinoteck, http://www.hinoteck.com). Image stacks of each structure were produced at different focal distances and later combined into a single image with Helicon Focus v. 7.6.1 (http://www.heliconsoft.com). The map showing the distribution of P. pacoi was created with QGIS v. 3.10 (http://www.qgis.org). Previous records of the species were taken from Kluge (1994) and Deler-Hernández et al. (2007) and georeferenced with GEOLocate (https:// www.geo-locate.org).

\section{Results}

\section{Poecilophlebia pacoi (Kluge, 1994)}

New record. CUBA - Santiago de Cuba province - Reserva de la Biósfera Baconao, Gran Piedra massif, tributary of Río Baconao, Gran Sofía; $19.995^{\circ} \mathrm{N}$, 075.581 ${ }^{\circ} \mathrm{W} ; 778 \mathrm{~m}$ a.s.1.; $0.40 \mathrm{~m}$ depth; 14.VII.2020; Juan Carlos Salazar Salina leg.; in backwaters inside leaves packs on sandy bottom; 1 mature nymph, + , in ethanol, CZCTR/CUB_JCS_2020_01.

Habitat parameters at the collection site measured in situ were: water temperature $21^{\circ} \mathrm{C}, \mathrm{pH} 7.40$, dissolved oxygen $6.88 \mathrm{mg} / \mathrm{L}$, conductivity $201.1 \mu \mathrm{S} / \mathrm{cm}$ and total dissolved solids $103.4 \mathrm{mg} / 1$.

Identification. Poecilophlebia pacoi is one of the 12 species of Leptophlebiidae presently reported from Cuba. Poecilophlebia nymphs can be distinguished from other genera of the family by the following combination of characteristics: gills gradually tapered apically without lateral processes, basal portion of gills III-V broad with many tracheal branches (Fig. 2A, D); labrum with denticles (Fig. 2B), width of labrum subequal to a little broader than clypeus (Fig. 2C); posterolateral projections present on abdominal segments III-IX; denticles on claws 

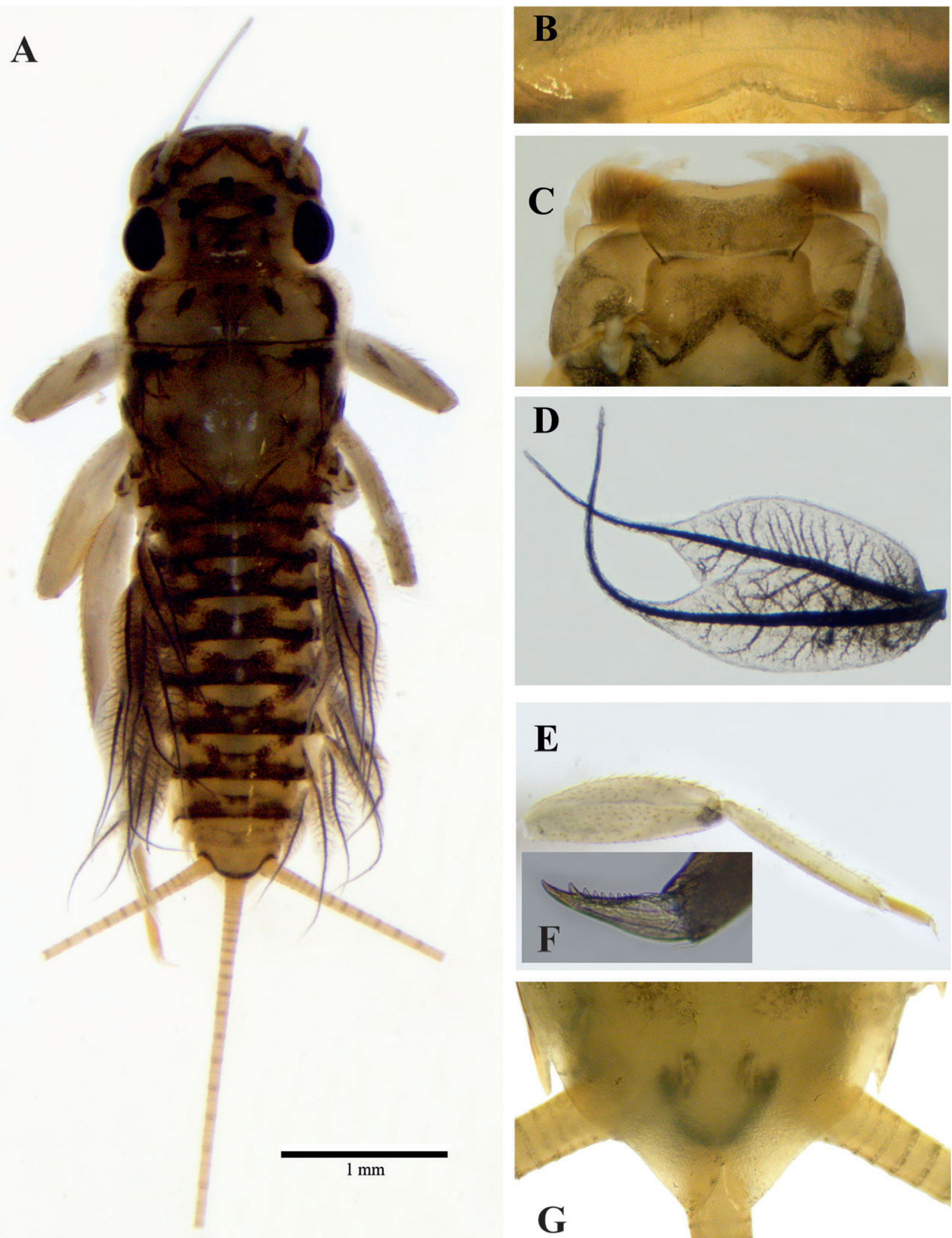

\section{$\mathbf{E}$}
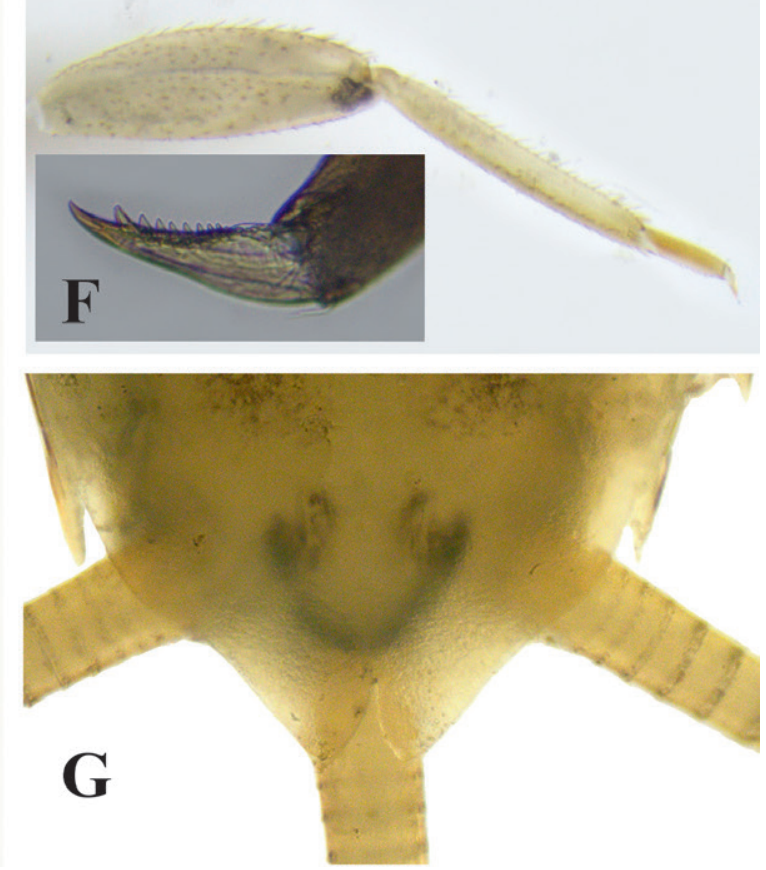

Figure 2. Poecilophlebia pacoi, female nymph A. Habitus. B. Denticles in the anteromedian margin of the labrum. C. Clypeus and labrum in dorsal view. D. Gill of the abdominal segment III. E. Hind leg. F. Tarsal claw, lateral view. G. Sternum IX, ventral view.

progressively larger apically (Fig. 2F) and apex of abdominal sternum IX incised (Fig. 2G); the species is easily recognized by an abdominal color pattern with four distinct dark marks dorsally on each tergum (Fig. 2A).
Additionally, P. pacoi can be distinguished from other species of the family by the presence of flattened tibiae (Fig. 2A, E), with concave dorsal surfaces visible in a microscope. 


\section{Discussion}

The new record expands the known distribution of Poecilophlebia pacoi approximately $55 \mathrm{~km}$ to the east in the Sierra Maestra mountain range (Fig. 1) and suggests the possibility of finding additional records farther from the type locality. This is the fifth official record of the species and the first after 13 years (Kluge 1994; DelerHernández et al. 2007). In addition, this new record is significant because other surveys in the same mountain range (López et al. 2004) or even in the catchment of the Baconao River (Martínez, et al. 2017) did not find the species.

The few historical records of $P$. pacoi could result from low local abundance (but see Deler-Hernández et al. 2007), lack of suitable habitat, difficulty of sampling, or the lack of surveys. Both low local abundance and lack of suitable habitat would be of concern for the conservation of $P$. pacoi. Therefore, additional surveys are needed to assess the conservation status of this mayfly. These surveys should be conducted in streams with similar conditions to those where P. pacoi has been found. Special attention should be paid to sample leaf packs from the bottom of streams. At present, at least two localities where P. pacoi occur are protected by the Cuban Protected Area System (Fig. 1).

\section{Acknowledgements}

We thank Y.S. Megna for the revision of the manuscript and personal support. As well Inês Corrêa Gonçalves, Janice G. Peters, and another anonymous reviewer for critically reading the manuscript. This work was partially supported by a project between VLIR-UOS (Belgium) and Universidad de Oriente (Cuba): 'Risk mitigation plan for biodiversity and food production to face climatic change in the eastern region of Cuba'. YT-C is supported by the Alexander von Humboldt Foundation through a Georg Forster Research Fellowship.

\section{Authors' Contributions}

JCS-S designed the study and conducted both the field and laboratory work. JCS-S and YT-C wrote the manuscript.

\section{References}

Deler-Hernández A, Megna YS, González-Lazo DD, Carcasés-Torres CN (2007) Insectos acuáticos y áreas prioritarias para la conservación en la cuenca alta del río Cauto (Santiago de Cuba, Cuba). Boletín Sociedad Entomológica Aragonesa 40: 451-461.

Gonzáles-Lazo DD, Naranjo JC (2007) Clave de identificación para larvas del orden Ephemeroptera presentes en Cuba. Revista de la Sociedad Entomológica Argentina 66 (1-2): 137-145.

Kluge N (1994) A revision of Leptophlebiidae from Cuba (Ephemeroptera). Zoosystematica Rossica 2 (2): 247-285.

López P, Naranjo C, Fernández JL, González-Lazo DD, Trapero A, Pérez J (2004) Insectos acuáticos del Parque Nacional 'La Bayamesa', Cuba. Boletín Sociedad Entomológica Aragonesa 35: 225-231.

Martínez, BT, Trapero A, Torres-Cambas Y, Roque FO (2017) Effects of wood density on aquatic insect communities in a Cuban montane rainforest stream. Neotropical Entomology 48: 527-537. https://doi.org/10.1007/s13744-019-00670-Z

Naranjo C, Peters JG, López P (2019) Ephemeroptera (Insecta) in Cuba. Insecta Mundi 0736: 1-52. 